\title{
Cultural adaptation, Reliability and Validity of the Turkish version of the Vulnerable Elders Survey (VES-13)
}

Savunmasız Yaşlı Anketi (VES-13) Türkçe Versiyonunun Kültürel Adaptasyonu, Güvenirlik ve Geçerliliği Soner BERŞE ${ }^{1}$, Sevgin SAMANCIOĞLU BAĞLAMA²

\begin{abstract}
The aim is to evaluate the validity and reliability of the Turkish version of the Vulnerable Elders Survey. This study is a methodological study. The survey was applied to 242 patients aging 74 or more. To collect data, the socio-demographic form, the Vulnerable Elder Survey, the Katz Activity of Daily Life and the Lawton\&Brody Instrumental Activity of Daily Life surveys were used. The research data were collected with a socio-demographic and clinical properties of the elderly patients and with the Vulnerable Elders Survey-Turkish Version (VES-13Tr). For the analysis of the data, Kendall's coefficient of concordance, factor analysis, Cronbach alpha coefficient, Pearson correlation analysis and student $\mathrm{t}$ test were used. For the language validity of the scale, the translationretranslation method was used. As for the content validity, the field experts reached consensus (Kendall's $=0.435, \mathrm{p}>0.05$ ). Kaiser-Meyer-Olkin (KMO) coefficient that applied to the scale has found to be 0.898 and the Barlet test result has been found highly significant $(\mathrm{x} 2=1589.773, \mathrm{p}=0.000)$. For VES-13Tr, the total-item test correlation values range from 0.33 to 0.72 and the Cronbach's alpha value has been calculated as 0.85 . Considering the results of the survey, it was found out that the adapted version of the VES-13 could be valid and reliable tool and that the VES-13 could be used for the evaluation of geriatric assessment.
\end{abstract}

Keywords: Elderly, Geriatric assessment, Nursing care, Vulnerability
ÖZ

Savunmasız Yaşlı Anketinin Türkçe versiyonunun geçerliliğini ve güvenilirliğini değerlendirmek amaçlanmıştır. Bu çalışma metodolojik bir çalışmadır. Anket, 74 yaş ve üzeri 242 hastaya uygulandı. Verileri toplamak için sosyo-demografik form, Savunmasız Yaşlı Anketi (VES-13Tr), Katz Temel Günlük Yaşam Aktiviteleri ve Lawton \& Brody Enstrümental Günlük Yaşam Aktiviteleri ölçekleri kullanıldı. Verilerin analizinde Kendall'ın uyum katsayısı, faktör analizi, Cronbach alfa katsayısı, Pearson korelasyon analizi ve student $\mathrm{t}$ testi kullanılmıştır. Ölçeğin dil geçerliliği için çeviri-yeniden çeviri yöntemi kullanılmıştır. İçerik geçerliliğinde, alandaki uzmanların fikirleri alındı (Kendall'ın $=0.435, \mathrm{p}>0.05$ ). Ölçeğe KaiserMeyer-Olkin (KMO) katsayısı 0.898 olarak bulundu ve Barlet testi sonucu oldukça anlamlıydı ( $x 2=1589.773, \quad \mathrm{p}=0.000)$. VES-13Tr için, madde faktör yükleri 0.33-0.72 arasında olup Cronbach alfa değeri 0.85 olarak hesaplanmıştır. Anketin sonuçlarına bakıldığında, VES-13'ün uyarlanmış versiyonunun geçerli ve güvenilir bir araç olduğu ve VES-13'ün geriatrik değerlendirilme için kullanılabileceği bulunmuştur.

Anahtar sözcükler: Yaşlı, Geriatrik değerlendirme, Hemşirelik bakımı, Savunmasızlık

Gaziantep Üniversitesi Girişimsel Olmayan Klinik Araştırmalar Etik Kurulu Başkanlı̆̆ı’ndan 2017/63 evrak saylsı, 27.02.2017 tarihi (Karar no: 63) ile etik izin alındı. Bu çalışma birinci yazarın yüksek lisans tez çalışmasından üretilmiş olup, Ulusal Sağlık Bakım Hizmetleri Kongresi'nde (11-12 Mayıs 2017, Ankara, Türkiye) sözel bildiri olarak sunulmuştur.

${ }^{1}$ Öğr.Gör., Soner BERŞE, Hemşirelik Esasları, Gaziantep Üniversitesi Hemşirelik Bölümü, sonerberse@gmail.com, ORCID: 0000-0001$9108-3216$

${ }^{2}$ Doç. Dr Sevgin SAMANCIOĞLU BAĞLAMA, İç Hastalıkları Hemşireliği, Muğla Sıtkı Koçman Üniversitesi Hemşirelik Bölümü, sevginsamancioglu@mu.edu.tr, ORCID: 0000-0002-0166-8294

İletişim / Corresponding Author:

Soner BERŞE

Geliş Tarihi / Received: 29.05.2021

e-posta/e-mail: sonerberse@gmail.com 


\section{INTRODUCTION}

Turkey is an emerging country with a rapid ageing process. ${ }^{1-3}$ In 2016, the ratio of the elderly to the total population was approximately $8.2 \%$. This ratio is expected to increase to $10.2 \%$ in 2023 and $20.8 \%$ in 2050. ${ }^{4}$ Moreover, this situation is observed worldwide. According to the World Health Organisation (WHO), $80 \%$ of the old population lives in the low and middle income countries; particularly, in Latin America and underdeveloped Asian countries, the elderly population is expected to increase by $300 \%$ by $2050 .^{5,6}$

Old people's quality of life is directly related to daily living activities. ${ }^{7}$ Furthermore, the psychological state is negatively affected when their quality of life and daily living activities are impaired. Several factors, such as their relationship with their family and friends, emotional state, economic factors, physical and material wellbeing and participation in leisure activities, can be added to these situations. ${ }^{8}$
Along with the ageing process, individuals wear out physically and mentally, and their level of dependency increases. ${ }^{9}$ Moreover, the treatment response time is generally longer for old people with chronic illnesses compared with that of the other age groups. Hence, it is important to determine whether old patients are prone to functional decline. ${ }^{10}$ The main aim of caring for the old people is to improve their quality of life by improving and preserving their functions. ${ }^{9}$ Along with ageing, deterioration of medical condition, multidrug use, confusion and environmental factors increase the risk of falling, and accordingly, it is difficult for old people, who have a fear of falling, to perform daily living activities. $^{2}$ The present study aimed to evaluate the vulnerable elders survey (VES13) for the Turkish language and culture by conducting validity and reliability studies of the adapted version.

\section{MATERIALS AND METHOD}

\section{Study design and participants}

This study has been methodologically designed. It was conducted in a Research and Application Hospital in Turkey between January and April 2017. The research cohort included 1061 old people. Based on the related available literature, the sample size could be said to be appropriate because each group was 10 times larger than the number of items in the scale. ${ }^{11,12}$ The scale included 13 variables. Thus, it has been considered that a sample of 130 (13 items $\times 10$ times $)$ is sufficient to represent the cohort. The study has been terminated with 242 old people who have been reached during the data collection period. Figure 1 presents the criteria for inclusion in the current study.

\section{Data Collection}

Face-to-face method was used by researchers to collect the data. The old people who accepted to participate in the study took approximately 20 minutes to complete the form.

\section{Data Collection Tools}

Two data collection tools were used in the current study.

\section{Old People Information Form}

The old people information form is a 15item questionnaire developed by the researchers in line with the related literature. ${ }^{13-17}$ It included questions regarding socio-demographic information (sex, age, marital status etc.) and disease characteristics (year of disease, type of treatment etc.).

\section{Vulnerable Elders Survey-13 (VES-13 ${ }^{\text {Tr}}$ )}

The vulnerable elders survey-13 (VES) was developed by Saliba et al. in $2001 .^{18}$ It comprises 4 main headings and 13 subheadings. The individual's age, how he/she feels compared with his/her peers, how many difficulties he/she faces in performing daily activities and the level of self-sufficiency in 
terms of personal need have been questioned using this scale. The survey, using which validity and reliability studies have been conducted in several countries, has been found to be convenient because it is highly related to the concept of comprehensive geriatric assessment (CGA) to predict functional decline in old people. ${ }^{16}$ The maximum and minimum score that can be obtained from the scale is seven and zero, respectively. A score of seven indicates functional decline and near-death individuals; contrarily, a score of zero indicates the healthiest old individual. The total score for this scale is not calculated. In this study, a score of three was considered the scale's breakpoint. Values below three indicate that the old people are healthy, whereas values of three and above indicate that the elderly are vulnerable or fragile.

\section{Katz Index of Independence in Activities of Daily Living (ADL)}

This scale has been developed by Katz et al. ${ }^{19}$ It specifies activities to provide the basic requirements that are valid for continuing life. The scale contains questions that investigate the self-care activities of individuals, such as feeding, bathing, transferring, dressing and continence. The individual is evaluated by giving one point if she/he can perform daily living activities and zero if he/she is dependent. A maximum and minimum score of six and zero, respectively, on the Katz scale is possible. The Cronbach's alpha co-efficient of this scale has been found to be $0.79 .{ }^{19}$

\section{The Lawton and Brody Instrumental Activities of Daily Living Scale (IADL)}

A scale for activities of daily living may provide an early warning of functional decline or may indicate the need for further evaluation ${ }^{20}$. Such a scale has been developed by Lawton and Brody. It is an 8item questionnaire that questions the individual's ability to use the telephone, shop, do housekeeping, use modes of transportation or taxi, handle finance, food preparation and responsibility for his/her own medications. Individuals are evaluated by giving one point if they can independently perform their living activities and zero if they are dependent. ${ }^{21}$

\section{Research Ethics}

The study was approved by the Ethics Committee of the Gaziantep University (Number: 2017/63). To carry out the study, consent was obtained from the institutions where the study was to be conducted, the developers of the measurement tool and the patients.

\section{Data Analysis}

The research data were analysed using the statistical analysis package software SPSS-21 (Chicago, USA). The patient's sociodemographic and clinical backgrounds were examined using mean scores, numbers and percentages. For language validity, the translation-retranslation method was used; for content validity, expert views were examined using Kendall's co-efficient of concordance. For the construct validity of the scale, exploratory factor analysis was conducted, and Student's t-test was used for independent groups. Statistical tests were two sided, with $\mathrm{p}<0.05$ being statistically significant. Cronbach's alpha internal consistency reliability co-efficient and Pearson correlation were used for reliability and descriptive statistics.

\section{RESULTS AND DISCUSSION}

\section{Language Validity}

First, we analysed language validity. The scale was translated from English to Turkish by an expert from the Department of Foreign Languages who was a Turkish native and knew both languages and cultures. After the most appropriate statements had been selected as a result of the translation, the scale was re-translated into English by two experts from the Department of Foreign Languages who were native Turkish speakers and also knew both the languages and 
cultures well, but had not seen the original English version of the scale. Following this, the statements in the re-translated version were compared with those in the original version of the scale, and the necessary corrections were made in line with the experts' views.

\section{Content Validity}

Each scale item has been scored out of 10 points to evaluate the content validity of the Turkish scale, which was created. Each item in the Turkish version of the scale, which was found to have language validity, was rated by five expert faculty members from the field of nursing (three clinical nurses and two doctors), who assigned scores ranging from 1 to 4 (1=inappropriate, 2=the item needs to be made appropriate, $3=$ appropriate but needs minor alterations and 4=very appropriate). The expert's opinions were determined to be compatible in terms of the content validity of the scale (Kendall's coefficient $=0.435, \mathrm{p}>0.05$ ). Following the language and content validity, a pilot application has been conducted with 10 old people having backgrounds similar to those of the research sample, and the scale was finalised. The pilot application data have not been used in the current study.

\section{Construct Validity and Internal Consistency}

To examine the construct validity of the scale, we investigated whether the original factorial structure of the scale is preserved by applying varimax rotation and principal component analysis to the items of the scale. Thus, the sampling adequacy calculated using the Kaiser-Meyer-Olkin (KMO) coefficient that applied to the scale has been

In the analysis, it has been found that the total item test correlation values range from 0.33 to 0.72 ; Cronbach's alpha value has been calculated as 0.85 (Table 2). The fact that the Cronbach's alpha co-efficient is > 0.5 supports the reliability of the test. Because the calculated total item test found to be 0.898 , and the Bartlett test result has been found to be highly significant ( $\mathrm{x} 2$ $=1589.773, \mathrm{p}=0.001$ ). To determine the scale reliability, in other words, the level of being free of measurement error, internal consistency levels of the scale items have been examined. Thus, Cronbach's alpha internal consistency coefficients have been calculated for all dimensions and subdimensions. The total item correlation coefficients of the scale have been calculated for each item (Table 1).

Table 1. VES-13 ${ }^{\text {Tr }}$ Exploratory Factor Analysis.

\begin{tabular}{ll}
\hline VES-13 ${ }^{\text {Tr }}$ Questions & Factor Loads \\
\hline Item 1 & 0.336 \\
Item 2 & 0.437 \\
Item 3a & 0.613 \\
Item 3b & 0.693 \\
Item 3c & 0.609 \\
Item 3d & 0.547 \\
Item 3e & 0.590 \\
Item 3f & 0.606 \\
Item 4a & 0.724 \\
Item 4b & 0.533 \\
Item 4c & 0.720 \\
\hline Item 4d & 0.672 \\
\hline
\end{tabular}

Explained Variance $\quad \% \quad 47.54$

correlation coefficients are often higher than the breakpoint of 0.30 , the scale form can be said to have normal internal consistency. As a result of the analysis, a 13-item measuring instrument with an eigenvalue of 6.180 that explains $47.54 \%$ of the total variance has been obtained; this measuring instrument has 
been observed to overlap with the items in $\mid$ the original form.

Table 2. Internal Validity of VES-13 ${ }^{\text {Tr }}$

\begin{tabular}{|c|c|c|c|}
\hline VES-13 ${ }^{\operatorname{Tr}}$ Questions & Scoring & n (\%) & $\begin{array}{l}\text { If the Item is Deleted } \\
\text { Cronbach's } \alpha\end{array}$ \\
\hline \multirow{2}{*}{ Item 1} & 1 & $204(84.3)$ & \multirow{2}{*}{0.849} \\
\hline & 3 & $38(15.7)$ & \\
\hline \multirow{2}{*}{ Item 2} & 0 & $107(44.2)$ & \multirow{2}{*}{0.847} \\
\hline & 1 & $135(55.8)$ & \\
\hline \multirow{2}{*}{ Item $3 \mathrm{a}$} & 0 & $163(67.4)$ & \multirow{2}{*}{0.843} \\
\hline & 1 & 79 (32.6) & \\
\hline \multirow{2}{*}{ Item $3 b$} & 0 & $170(70.2)$ & \multirow{2}{*}{0.842} \\
\hline & 1 & $72(29.8)$ & \\
\hline \multirow{2}{*}{ Item $3 c$} & 0 & $194(80.2)$ & \multirow{2}{*}{0.845} \\
\hline & 1 & $48(19.8)$ & \\
\hline \multirow{2}{*}{ Item $3 d$} & 0 & $195(80.6)$ & \multirow{2}{*}{0.846} \\
\hline & 1 & $47(19.4)$ & \\
\hline \multirow{2}{*}{ Item $3 \mathrm{e}$} & 0 & $137(56.6)$ & \multirow{2}{*}{0.843} \\
\hline & 1 & $105(43.4)$ & \\
\hline \multirow{2}{*}{ Item $3 f$} & 0 & $113(46.7)$ & \multirow{2}{*}{0.843} \\
\hline & 1 & $129(53.3)$ & \\
\hline \multirow{2}{*}{ Item $4 \mathrm{a}$} & 0 & $151(62.4)$ & \multirow{2}{*}{0.826} \\
\hline & 4 & $91(37.6)$ & \\
\hline \multirow{2}{*}{ Item $4 b$} & 0 & $174(71.9)$ & \multirow{2}{*}{0.844} \\
\hline & 4 & $68(28.1)$ & \\
\hline \multirow{2}{*}{ Item $4 \mathrm{c}$} & 0 & $196(81.0)$ & \multirow{2}{*}{0.823} \\
\hline & 4 & $46(19.0)$ & \\
\hline \multirow{2}{*}{ Item $4 d$} & 0 & $165(68.2)$ & \multirow{2}{*}{0.830} \\
\hline & 4 & 77 (31.8) & \\
\hline \multirow{2}{*}{ Item $4 \mathrm{e}$} & 0 & $196(81.0)$ & \multirow{2}{*}{0.825} \\
\hline & 4 & $46(19.0)$ & \\
\hline TOTAL VES-13 $^{\text {Tr }}$ & - & - & 0.850 \\
\hline
\end{tabular}

\section{Demographic Characteristics of Old People}

Of all the old people, $51.7 \%$ were females, $64.0 \%$ were married and $50.8 \%$ were literate. Approximately $93.4 \%$ had health insurance, and $62.4 \%$ belonged to the middle class. The family types were extended for $50.0 \%$, nuclear for $40.1 \%$ and fragmented for $9.9 \%$.
Approximately $29.3 \%$ lived with their spouse and children, $28.5 \%$ with their sons and $25.6 \%$ with their spouse, and $30.6 \%$ reported to have very good family relations. In addition, $73.1 \%$ had at least one chronic illness (Table 3). 
Table 3. Demographic Characteristics of The Elderly

\begin{tabular}{|c|c|c|c|}
\hline & $\begin{array}{l}\text { VES-13 }{ }^{\operatorname{Tr}}<3^{\mathrm{a}} \\
\text { n }(\%)\end{array}$ & 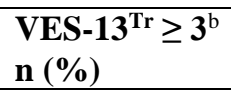 & $\begin{array}{l}\text { Total } \\
\text { n }(\%) \\
\end{array}$ \\
\hline \multicolumn{4}{|l|}{ Age (years) } \\
\hline $74-84$ & $108(52.9)$ & $96(7.1)$ & $204(84.3)$ \\
\hline$\geq 85$ & $7(18.4)$ & $31(81.6)$ & $38(15.7)$ \\
\hline \multicolumn{4}{|l|}{$\overline{\text { Sex }}$} \\
\hline Female & $58(46.4)$ & $67(51.7)$ & $125(51.7)$ \\
\hline Male & $57(48.7)$ & $60(48.3)$ & $117(48.3)$ \\
\hline \multicolumn{4}{|l|}{ Marital Status } \\
\hline Married & $80(51.6)$ & $75(48.4)$ & $155(64)$ \\
\hline Single & $35(40.2)$ & $52(59.8)$ & $87(36)$ \\
\hline \multicolumn{4}{|l|}{ Education Level } \\
\hline Literate & $41(34.5)$ & $78(65.5)$ & $119(49.2)$ \\
\hline Illiterate & $74(60.2)$ & $49(39.8)$ & $123(50.8)$ \\
\hline \multicolumn{4}{|l|}{ Health Insurance } \\
\hline Yes & $109(48.2)$ & $117(51.8)$ & $226(93.4)$ \\
\hline No & $6(37.5)$ & $10(62.5)$ & $16(6.6)$ \\
\hline \multicolumn{4}{|l|}{ Income Status } \\
\hline High & $33(60)$ & $22(40)$ & $55(22.7)$ \\
\hline Middle & $72(47.7)$ & $79(52.3)$ & $151(62.4)$ \\
\hline Low & $10(27.8)$ & $26(72.2)$ & $36(14.9)$ \\
\hline \multicolumn{4}{|l|}{ Family Type } \\
\hline Nuclear & $54(55.7)$ & $43(44.3)$ & $97(40.1)$ \\
\hline Extended & $55(45.5)$ & $66(54.5)$ & $121(50.0)$ \\
\hline Fragmented & $6(25)$ & $18(75)$ & $24(9.9)$ \\
\hline \multicolumn{4}{|l|}{ Living With } \\
\hline Spouse & $32(51.6)$ & $30(48.4)$ & $62(25.6)$ \\
\hline Daughter & $7(58.3)$ & $5(41.7)$ & $12(5.0)$ \\
\hline Son & $22(31.9)$ & $47(68.1)$ & $69(28.5)$ \\
\hline Spouse and children & $41(57.7)$ & $30(42.3)$ & $71(29.3)$ \\
\hline Caregiver & $13(46.4)$ & $15(53.6)$ & $28(11.6)$ \\
\hline \multicolumn{4}{|l|}{ Family Relations } \\
\hline Very good & $42(56.8)$ & $32(43.2)$ & $74(30.6)$ \\
\hline Good & $43(46.7)$ & $49(53.3)$ & $92(38.0)$ \\
\hline Fair & $19(34.5)$ & $36(65.5)$ & $55(22.7)$ \\
\hline Poor & $10(52.6)$ & $9(47.4)$ & $19(7.9)$ \\
\hline Very poor & $1(50)$ & $1(50)$ & $2(0.8)$ \\
\hline \multicolumn{4}{|l|}{ Chronic Illness } \\
\hline Yes & $81(45.8)$ & $96(54.2)$ & $177(73.1)$ \\
\hline No & $34(52.3)$ & $31(47.7)$ & $65(26.9)$ \\
\hline
\end{tabular}

${ }^{\mathrm{a}}$ VES- $13^{\mathrm{TR}}<3$ : healthy, ${ }^{\mathrm{b}} \mathrm{VES}-13^{\mathrm{TR}} \geq 3$ : vulnerable

\section{Relationship between VES-13Tr and Activities of Daily Living}

In the VES-13Tr evaluation, the breakpoint has been regarded as 'vulnerable old' $\geq 3$ and 'healthy old' for scores $<3$. In the 'vulnerable old' group, the ADL score average has been calculated as $5.23 \pm 1.75$, whereas the IADL score average has been calculated as $3.50 \pm 2.31$. There is a statistically significant relationship between VES-13Tr and ADL ( $<<0.001$; Table 4).
Positive, moderate and significant relationships have been observed between the scores of VES-13Tr and Katz ADL Scale [r $(242)=0.36, p<0.001)]$. A significant positive and strong relationship has been found between VES-13TR and Lawton IADL Scale scores $[\mathrm{r}(242)=0.72, \mathrm{p}<0.001)]$. In other words, as the IADL score decreases, the level of dependency increases. According to table 5 , compared with the ADL score, the VES$13 \mathrm{Tr}$ scale better presents the IADL score. 
Table 4. Comparison of ADL and IADL Point Averages of The Elderly According To The VES-13 ${ }^{\mathrm{Tr}}$ Status

\begin{tabular}{lll}
\hline & ADL & IADL \\
VES-13 & & \\
& & \\
VES-13 & & \\
& & \\
& & \\
& & \\
& $5.97 \pm 0.28$ & \\
& $\mathrm{tr}=4.513 \pm 1.75$ & $3.50 \pm 2.31$ \\
& $\mathrm{p}=0.001$ & $\mathrm{t}=13.165$ \\
& $\mathrm{p}=0.001$ \\
\hline
\end{tabular}

ADL, activities of daily living; IADL, instrumental activities of daily living

Table 5. Correlation Between VES-13 ${ }^{\text {Tr }}$ and Daily Living Activities

\begin{tabular}{|c|c|c|c|c|}
\hline & \multicolumn{2}{|c|}{ ADL } & \multicolumn{2}{|c|}{ IADL } \\
\hline & $\mathbf{R}$ & $\mathbf{p}$ & $\mathbf{R}$ & $\mathbf{p}$ \\
\hline VES-13 ${ }^{\operatorname{Tr}}$ & $-0.36^{* *}$ & 0.001 & $-0.72 * *$ & 0.001 \\
\hline
\end{tabular}

Studies investigating whether the scale is valid and reliable have been carried out in different countries. ${ }^{13,15,16,22-25}$ In all these studies, a score of three has been considered as the breakpoint. In addition, the scale has been found to be highly reliable in CGA. $13,15,16,22-25$

Kroc et al. (2016) examined the validity and reliability of the VES-13 scale by conducting basic and IADL and mental and geriatric depression evaluations. ${ }^{15}$ According to the results of his study, the VES-13 scale can be used to evaluate the functional status of old people. ${ }^{15}$ EQ-5D-5L and VAS have been used for general health assessment in a study conducted on gastrointestinal cancer patients wherein one of the old people belonged to the vulnerable group. The study concluded that the scale is a valid and reliable instrument and that it is able to assess the functional status of the patient group. In addition, the Cronbach's alpha values of the scale have been found to be $0.84 .^{13}$
In a study conducted by Luz et al. on 272 cancer patients, the VES-13 scale has been found to be valid and reliable for the Brazilian population. ${ }^{23}$ Another study has estimated the CGA-oriented 'fragility' syndrome in patients aged $>65$, wherein $78 \%$ of the VES-13 score has been determined to demonstrate fragility syndrome. ${ }^{22}$ Maia et al. (2012) have also stated that the scale is valid and reliable as well as easy to implement. The scale with a 0.70 Cronbach's alpha value defines the vulnerable group at a better level ${ }^{24}$. In their study sample, Luciani et al. (2010) have reported that $53.7 \%$ of the old people belong to the vulnerable group. It has been determined that the scale with 0.71 Cronbach's alpha value is valid and reliable and can be used for CGA. ${ }^{16}$ The reliability rate is considerably high in terms of CGA as reported by a study involving an elderly group wherein half the participants belonged to the vulnerable group. ${ }^{25}$ 


\section{CONCLUSION AND RECOMMENDATIONS}

Elderly individuals can be better evaluated in rehabilitation units and clinics; however, brief evaluations in ambulatory units are more effective. CGA is highly significant in terms of the evaluation of elderly individuals, because it includes physical, psychological and social evaluation. VES-13 is an efficient scale that has been particularly developed for CGA and has demonstrated its reliability and sensitivity in several studies. By examining the results of this study, the vulnerable elders survey has been determined to be a valid and reliable evaluation tool for the elderly Turkish people.

REFERENCES

1. Ağar, A. (2020). "Yaşlılarda Ortaya Ç1kan Fizyolojik Değişiklikler". Ordu Üniversitesi Hemşirelik Çalışmalar Dergisi, 3 (3), 347-354

2. Cinarlı, T. ve Koç, Z. (2015). "65 Yaş ve Üzeri Yaşlılarda Düşme Risk ve Korkusunun Günlük Yaşam Aktiviteleri ve Yaşam Kalitesi Üzerine Etkisi". Gümüşhane Üniversitesi Sağlık Bilim Dergisi, 4 (4), 660-679.

3. Ulutaşdemir, N. (2019). Yaşlı Bireylerde Sağlığın Korunması ve Geliștirilmesi. In: Ü. Sevil and V. Bayram Değer (Ed.). Geriatrik Disiplinlinler Arası Yaklaşım (525). İstanbul: Güven Plus Grup.

4. Türkiye İstatistik Kurumu. (2021). "İstatistiklerle Yaşlilar".Retrieved:https://data.tuik.gov.tr/Bulten/Index?p =Elderly-Statistics-2020-37227 (Accessed: Feburary 20, 2021).

5. Kutsal, Y.G. (2016). "Yaşlanan Dünyanın Yaşlanan Insanları". Retrieved: http://e-kutuphane.teb.org.tr/pdf/teb akademi/geriatri_2009/5.pdf (Accessed: November 28, 2016).

6. World Health Organization. (2015). "Ageing and health". Retrieved: http://www.who.int/mediacentre/factsheets/fs 404/en. (Accessed: March 26, 2017).

7. Giebel, C.M, Sutcliffe, C. and Challis, D. (2015) "Activities of Daily Living and Quality of Life Across Different Stages Of Dementia: A UK Study". Aging Mental Health, 19 (1), 63-71.

8. Unsar, S, Dindar, I. and Kurt, S. (2015). "Activities of Daily Living, Quality of Life, Social Support and Depression Levels of Elderly İndividuals in Turkish Society". The Journal of the Pakistan Medical Association, 65 (6), 642-646.

16. Luciani, A, Ascione, G, Bertuzzi, C. et al. (2010) "Detecting Disabilities in Older Patients with Cancer: Comparison between Comprehensive Geriatric Assessment and Vulnerable Elders Survey-13". J Clin Oncol, 28 (12), 2046-2050.

17. Min, L.C., Elliott, M.N., Wenger, N.S. and Saliba, D. (2006). "Higher Vulnerable Elders Survey Scores Predict Death and Functional Decline in Vulnerable Older People". J Am Geriatr Soc, 54 (3), 507-511.

18. Saliba, D, Elliott, M, Rubenstein, L.Z. et al. (2001). "The Vulnerable Elders Survey: A Tool for Identifying Vulnerable Older People in the Community". J Am Geriatr Soc, 49 (12), 1691-1699.

19. Katz, S, Ford, A.B, Moskowitz, R.W. et al. (1963) "Studies of Illness in the Aged. The Index of ADL: A Standardized Measure of Biological and Psychosocial Function". J Am Med Assoc, 185 (12), 914-919.
9. Demir Akça, A.S, Saraçl, Ö, Emre, U. et al. (2014). "Hastanede Yatan Yaşlılarda Bilişsel İşlevlerin Günlük Yaşam Aktiviteleri, Depresyon, Anksiyete ve Klinik Değiş̧kenlerle İlişskisi". Noropsikiyatri Arsivi, 51 (3), 267 274.

10. Paterson, D.H. and Warburton, D.E. (2010). "Physica Activity and Functional Limitations in Older Adults: A Systematic Review Related to Canada's Physical Activity Guidelines". Int J Behav Nutr Phys Act, 7 (1), 38.

11. Büyüköztürk, Ş. (2017). Sosyal Bilimler İçin Veri Analizi El Kitabı. Ankara: Pegem Akademi.

12. Cabrera-Nguyen, P. (2010). "Author Guidelines for Reporting Scale Development and Validation Results in the Journal of the Society for Social Work and Research". J Soc Social Work Res, 1 (2), 99-103.

13. Carneiro, F, Sousa, N, Azevedo, L.F. and Saliba, D. (2015). "Vulnerability in Elderly Patients with Gastrointestinal Cancer - Translation, Cultural Adaptation and Validation of The European Portuguese Version of the Vulnerable Elders Survey (VES-13)". BMC Cancer, 15 (1), 723

14. Deckx, L, Van Den Akker, M, Daniels, L. et al. (2015) "Geriatric Screening Tools Are of Limited Value To Predict Decline in Functional Status and Quality of Life: Results of A Cohort Study". BMC Fam Pract, 16 (2), 30.

15. Kroc, L, Socha, K, Soltysik, B.K. et al. (2016). "Validation of the Vulnerable Elders Survey-13 (VES-13) in Hospitalized Older Patients". Eur Geriatr Med, 7 (5), 449-453.

20. Graf, C. (2008). "The Lawton Instrumental Activities of Daily Living Scale". AJN The American Journal of Nursing, 108 (4), 52-62.

21. Lawton, M.P. and Brody, E.M. (1969). Assessment of Older People: Self-Maintaining and Instrumental Activities of Daily Living. Gerontologist, 9 (3), 179-186.

22. Kenig, J, Richter, P, Zychiewicz, B. and Olszewska, U. (2014). "Vulnerable Elderly Survey 13 as A Screening Method for Frailty in Polish Elderly Surgical PatientProspective Study". Pol Przegl Chir, 86 (3), 126-131.

23. Luz, L.L, Santiago, L.M, Silva, J.F.S. and Mattos, I.E. (2015). "Psychometric Properties of the Brazilian Version of the Vulnerable Elders Survey-13 (VES-13)". Cad Saúde Pública, 31 (3), 507-515.

24. Maia, F. de O.M, Duarte Y.A de, O, Secoli, S.R. et al. (2012). "Cross-cultural adaptation of the vulnerable elders survey-13(ves-13): Helping in the Identification of Vulnerable Older People". Rev da Esc Enferm, 46 (2), 
116-122.

25. Mohile, S.G, Bylow, K, Dale, W. et al. (2007). "A pilot Study of The Vulnerable Elders Survey-13 Compared
With The Comprehensive Geriatric Assessment for Identifying Disability in Older Patients With Prostate Cancer Who Receive Androgen Ablation". Cancer, 109 (4), 802-810. 